\title{
Genotypic and Pathotypic Diversity in Xanthomonas oryzae pv. oryzae in Nepal
}

\author{
Tika B. Adhikari, T. W. Mew, and Jan E. Leach
}

First author: Department of Plant Pathology, Institute of Agriculture and Animal Science (IAAS), Tribhuvan University, Nepal; second author: Division of Entomology and Plant Pathology, International Rice Research Institute (IRRI), MCPO Box 3127, 1271 Makati City, Philippines; and third author: Department of Plant Pathology, Kansas State University, Throckmorton Plant Sciences Center, Manhattan 66506-5502. Current address of T. B. Adhikari: Agrium Inc., 104-111 Research Drive, Saskatoon, SK, S7N 3R2 Canada. Accepted for publication 18 April 1999.

\begin{abstract}
Adhikari, T. B., Mew, T. W., and Leach, J. E. 1999. Genotypic and pathotypic diversity in Xanthomonas oryzae pv. oryzae in Nepal. Phytopathology 89:687-694.

Among the 171 strains of Xanthomonas oryzae pv. oryzae (the bacterial blight pathogen of rice) collected from eight rice-producing zones in Nepal, 31 molecular haplotypes were distinguished using two polymerase chain reaction-based assays. Six common haplotypes represented nearly $63 \%$ of the strains, and some haplotypes were geographically dispersed. Multiple correspondence analysis divided the collection into five putative genetic lineages. Lineages 1, 2, and 4 were the most frequently detected and occurred in diverse geographic populations. Twenty-six pathotypes (virulence phenotypes) of $X$. oryzae pv. oryzae were identified using 11 near-isogenic rice lines, each containing a single gene for resistance. The 26 patho-
\end{abstract}

ABSTRACT types grouped into five clusters, and cluster 1 contained wide virulence spectrum strains from all geographic populations. Although molecular variation was greatest between strains of different virulence phenotypes, some variation was observed among strains with identical virulence. There was a weak correlation $(r=0.52)$ between molecular haplotypes and virulence phenotypes. There are two major groups of $X$. oryzae pv. oryzae in Nepal. One group consists of strains with high molecular polymorphism and many pathotypes that are either virulent to the 11 major resistance genes or avirulent only to Xa21. Strains in the second group have low molecular polymorphism and are avirulent to $\mathrm{Xa} 4, \mathrm{xa}$, Xa7, and $\mathrm{Xa21}$.

Additional keywords: insertion sequence element, Oryza sativa, population biology.
Bacterial blight of rice (Oryza sativa L.), caused by Xanthomonas oryzae pv. oryzae (50), is a major threat to rice production in Asia $(36,37)$ and, in particular, Nepal $(2-4)$. The disease is widely distributed in the hills and plains of Nepal $(5,7)$. Yield reductions of up to $26 \%$, directly attributable to bacterial blight infection, are common (4), although losses may be higher during severe epidemics. Host resistance is an important component of an integrated disease management program for bacterial blight; however, the pathogen population invariably changes and overcomes the deployed resistance $(38,39)$. So far, 21 resistance genes have been identified and utilized in rice breeding programs $(41,55,56)$. In the Philippines, the bacterial blight resistance gene $\mathrm{Xa} 4$ was first deployed into modern rice varieties during the early 1970s (25). However, compatible races of $X$. oryzae pv. oryzae soon appeared, possibly as a result of selection pressure due to the presence of race-specific resistant cultivars (39).

Although many sources of resistance to bacterial blight have been identified in rice-growing countries in Asia $(25,41)$, breeding rice for resistance to $X$. oryzae pv. oryzae in Nepal is still in an early developmental stage. Information on the existing population structure of the pathogen in a region can be useful in the identification and characterization of useful resistant germ plasm (31). For example, Nelson et al. (40) used knowledge of the $X$. oryzae pv. oryzae population structure in the Philippines to select representative strains for screening rice germ plasm collections for resistance. To assist the Nepalese rice breeding program and to lay the

Corresponding author: T. B. Adhikari; E-mail address: tadhikari@sprint.ca

Requests for reprints should be sent to J. E. Leach; E-mail address: jeleach@ksu.edu

Publication no. P-1999-0519-01R

(c) 1999 The American Phytopathological Society groundwork for epidemiological studies, we previously conducted a preliminary analysis of the population structure of $X$. oryzae pv. oryzae in Nepal (9). A collection of strains was analyzed by virulence typing and DNA fingerprinting by restriction fragment length polymorphism (RFLP) analysis using insertion sequence element IS $1112(22,27-31,57)$ and a family of avirulence genes as probes $(20,29)$. This analysis, based on $45 X$. oryzae pv. oryzae strains from Nepal, suggested that genetic diversity of the pathogen population was higher in Nepal than in most other Asian countries (9). Most of the Nepalese strains were virulent to rice cultivars containing the bacterial blight resistance genes $\mathrm{Xa4}, \mathrm{xa5}$, and $\mathrm{Xa10}$, the genes present in the commonly used International Rice Research Institute (IRRI) rice differential cultivars $(9,36)$.

Because our previous studies $(1,6,9)$ had rather limited sample sizes, the database containing information on genetic variation in the populations of $X$. oryzae pv. oryzae in Nepal was limited. Therefore, we examined the relationship between molecular and virulence polymorphisms in $X$. oryzae pv. oryzae populations using an expanded collection of 171 strains from eight rice-producing zones of Nepal. Our overall goal was to determine whether molecular and virulence polymorphisms were correlated and if the information could be used in breeding strategies. Based on the previous study (9), we predicted that each zone in Nepal would contain high genotypic diversity. If this is true, then the identification of the same molecular haplotype in more than one zone would suggest that migration of that haplotype had occurred through movement of rice germ plasm.

The populations of $X$. oryzae pv. oryzae in Nepal were further evaluated for virulence on an expanded series of 11 near-isogenic lines. In earlier studies, we had observed multiple pathotypes within each lineage of $X$. oryzae pv. oryzae $(1,9)$. Thus, we predicted that pathogenicity can evolve rapidly within genetic lineages, leading to high pathogenic diversity among strains within lineages. Infor- 
mation from this study would establish a baseline for monitoring the distribution of unique $X$. oryzae pv. oryzae haplotypes and their spread into other areas of rice production.

\section{MATERIALS AND METHODS}

Bacterial strains. In all, 171 strains were collected from eight riceproducing zones in Nepal: Mechi, Koshi, Janakpur, Narayani, Gandaki, Lumbini, Rapti, and Bheri (Table 1). These are major zones for rice production in Nepal, and bacterial blight is a serious disease in these areas $(2,3,7)$. Populations of $X$. oryzae pv. oryzae were collected from the plains (100 to $500 \mathrm{~m}$ ) and the hills (500 to

TABLE 1. Genotypic and pathotypic diversity as measured by the normalized Shannon information statistic $\left(H^{\prime}\right)$ for Xanthomonas oryzae pv. oryzae populations in Nepal

\begin{tabular}{lrrrrrrrr}
\hline & \multicolumn{3}{c}{ Genotypic diversity $^{\mathrm{a}}$} & & \multicolumn{3}{c}{ Pathotypic diversity $^{\mathrm{b}}$} \\
\cline { 2 - 3 } \cline { 7 - 8 } Zone & $N$ & No. of haplotypes & $H^{\prime c}$ & & $N$ & No. of pathotypes & $H^{\prime c}$ \\
\hline Mechi & 38 & 17 & 0.90 & 28 & 13 & 0.86 \\
Koshi & 7 & 3 & 0.98 & 6 & 5 & 0.97 \\
Janakpur & 20 & 7 & 0.75 & 20 & 7 & 0.79 \\
Narayani & 42 & 18 & 0.88 & 25 & 11 & 0.86 \\
Gandaki & 29 & 9 & 0.74 & 29 & 11 & 0.79 \\
Lumbini & 20 & 12 & 0.92 & 11 & 5 & 0.80 \\
Rapti & 5 & 3 & 0.87 & 5 & 4 & 0.96 \\
Bheri & 10 & 6 & 0.98 & 4 & 3 & 0.94 \\
\hline
\end{tabular}

${ }^{a}$ Haplotypes are based on repetitive sequence-based polymerase chain reaction (rep-PCR) with the enterobacterial repetitive intergenic consensus (ERIC) primer and insertion sequence-based polymerase chain reaction (IS-PCR) with the $\mathrm{J} 3$ primer.

${ }^{\mathrm{b}}$ Pathotypes of $X$. oryzae pv. oryzae were determined on 11 near-isogenic lines containing a single gene for resistance.

${ }^{c}$ Genotypic and pathotypic diversity was estimated by the normalized Shannon information statistic (11) as described in the text. No significant differences $(P<0.05)$ were observed among $H^{\prime}$ values when compared by $t$ tests.
$1,200 \mathrm{~m}$ ) and from improved or traditional rice cultivars between 1987 and 1995. At each site, samples were collected from different rice fields, experimental plots, or farmers' plantings. Sample size varied (Table 1) depending on the prevalence of the disease. Sample size within each zone ranged from 5 to 42 .

Bacteria were isolated from infected leaves as described previously (6). A single colony of $X$. oryzae pv. oryzae was purified either on peptone sucrose agar (PSA) (42) or modified Wakimoto's medium (20 g of sucrose, $5 \mathrm{~g}$ of peptone, $0.5 \mathrm{~g}$ of $\mathrm{Ca}\left(\mathrm{NO}_{3}\right)_{2} \cdot 4 \mathrm{H}_{2} \mathrm{O}$, $1.82 \mathrm{~g}$ of $\mathrm{Na}_{2} \mathrm{HPO}_{4} \cdot 7 \mathrm{H}_{2} \mathrm{O}, 0.05 \mathrm{~g}$ of $\mathrm{FeSO}_{4} \cdot 7 \mathrm{H}_{2} \mathrm{O}$, and $18 \mathrm{~g}$ of Bacto agar per liter) (23) and incubated at $28^{\circ} \mathrm{C}$ for $96 \mathrm{~h}$ (6). For longterm storage, strains were maintained in $15 \%$ glycerol at $-80^{\circ} \mathrm{C}$ or as lyophilized cultures. For DNA extraction, bacteria were grown overnight in nutrient broth with shaking at $28^{\circ} \mathrm{C}$.

DNA isolation. Extraction of genomic DNA from each strain of $X$. oryzae pv. oryzae was performed by the lysozyme-sodium dodecyl sulfate lysis method of Owen and Borman (43) as modified by Leach et al. (30). DNA of each strain was quantified by absorbance at $260 \mathrm{~nm}$ using an UV spectrophotometer (Beckman Coutler Inc., Fullerton, CA) and stored at $-20^{\circ} \mathrm{C}$. DNA concentrations were adjusted to $50 \mathrm{ng} / \mu \mathrm{l}$ and verified by comparing with a $1-\mathrm{kb}$ ladder (Promega Corp., Madison, WI) on 1.5\% agarose gels.

rep-Polymerase chain reaction (PCR) and IS-PCR analyses. Genotypic diversity was evaluated by two PCR-based assays, repetitive sequence-based PCR (rep-PCR) $(13,33-35,49,52,53)$ and a PCR assay based on the amplification of sequences between copies of the endogenous $X$. oryzae pv. oryzae insertion sequence (IS) elements, IS1112 and IS1113, that we call IS-PCR. The repetitive primer sequences corresponding to ERIC (ERIC1R [5'-ATGTAAGCTCCTGGGGATTCAC-3'] and ERIC2 [5'-AAGTAAGTGACTGGGGTGAGCG-3']) (13,21,33-35,49,51-53) and the IS-primer J3 (5'-GCTCAGGTCAGGTCGCCTGG-3') were selected from our previous study $(8,51)$ and used to determine if they could reveal polymorphism in $X$. oryzae pv. oryzae strains in Nepal. The IS-

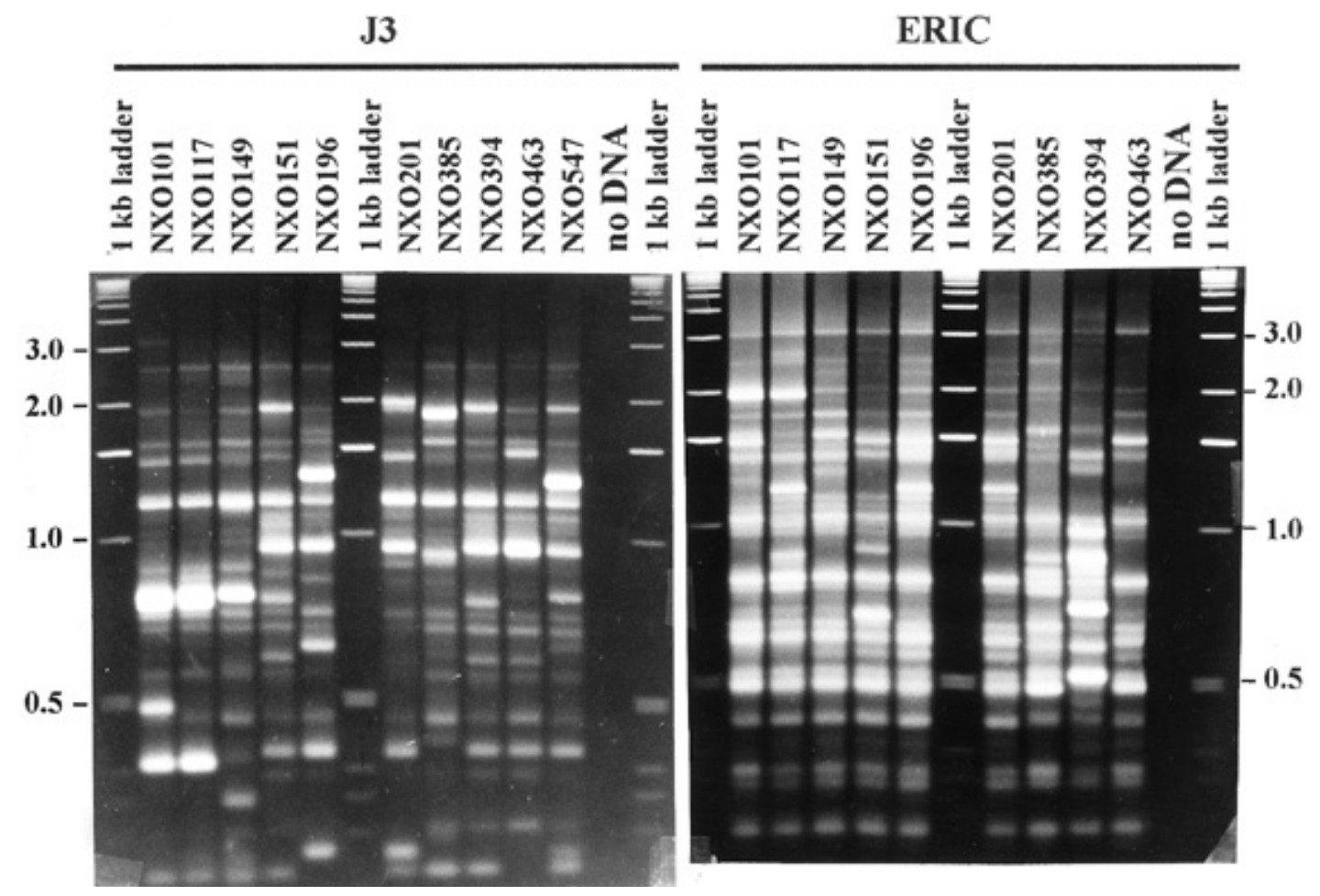

Fig. 1. Agarose gel showing representative haplotypes of Xanthomonas oryzae pv. oryzae from Nepal generated by repetitive sequence-based polymerase chain reaction (rep-PCR) with the enterobacterial repetitive intergenic consensus (ERIC) primer and an insertion element, IS1112, from X. oryzae pv. oryzae (IS-PCR) with the J3 primer. After amplification by PCR, the DNA fragments were separated by agarose gel electrophoresis and visualized by staining with ethidium bromide. Numbers to the right indicate molecular weight in base pairs. Ten haplotypes can be observed and their haplotype (no.), lineage (L), and origin (zone), respectively, are as follows: NXO101 (1, L1, and Mechi), NXO117 (2, L1, and Rapti), NXO149 (5, L1, and Mechi), NXO151 (20, L4, and Mechi), NXO196 (21, L4, and Rapti), NXO201 (22, L4, and Lumbini), NXO385 (30, L5, and Narayani), NXO394 (23, L4, and Mechi), NXO463 (8 [the most predominant haplotype], L2, and Lumbini), and NXO547 (9, L2, and Janakpur). 
PCR and rep-PCR primers were synthesized by Life Technologies (Gibco BRL, Bethesda, MD) and by the Biotechnology Microchemical Core Facility at Kansas State University, respectively.

All amplifications were carried out in a final volume of $25 \mu \mathrm{l}$ under a layer of mineral oil (Sigma Chemical Co., St. Louis) and were performed in a programmable thermal cycler (model PTC-100; MJ Research Inc., Watertown, MA). The reaction mixtures for ISPCR contained (final concentrations) $50 \mathrm{pmol}$ of primer, $50 \mathrm{ng}$ of template DNA, $312.5 \mu \mathrm{M}$ each deoxynucleoside triphosphate (dNTP) (Sigma Chemical Co.), 2 units of Taq polymerase (Promega Corp.), and $10 \%$ (vol/vol) dimethyl sulfoxide (DMSO). The $5 \times$ reaction buffer stock solution contained $10 \mathrm{mM}$ Tris- $\mathrm{HCl}$ (pH 8.3), $25 \mathrm{mM}$ $\mathrm{KCl}, 3.5 \mathrm{mM} \mathrm{MgCl}_{2}$, and $160 \mathrm{ng}$ of bovine serum albumin per $\mathrm{ml}$. The amplification with the IS-PCR primer began with a denaturation phase at $95^{\circ} \mathrm{C}$ for $7 \mathrm{~min}$ followed by 30 cycles of denaturation at $94^{\circ} \mathrm{C}$ for $1 \mathrm{~min}$ and annealing and extension at $68^{\circ} \mathrm{C}$ for 3 min each. The final extension cycle was at $65^{\circ} \mathrm{C}$ for $15 \mathrm{~min}$ followed by incubation at $4^{\circ} \mathrm{C}$ for $20 \mathrm{~h}$.

Conditions for rep-PCR were as described by de Bruijn (13), except that the final dNTP concentration was adjusted to $625 \mu \mathrm{M}$ (51). For rep-PCR, reaction mixtures contained 50 pmol of each primer, $50 \mathrm{ng}$ of template DNA, $50 \mathrm{mM}$ dNTPs, 2 units of Taq DNA polymerase, and $10 \%$ ( $\mathrm{vol} / \mathrm{vol}) \mathrm{DMSO}$. The $5 \times$ reaction buffer stock solution included $83 \mathrm{mM}$ ammonium sulfate, $335 \mathrm{mM}$ Tris- $\mathrm{HCl}$ ( $\mathrm{pH} 8.0$ ), $33.5 \mathrm{mM}$ magnesium chloride, $33.5 \mu \mathrm{M}$ EDTA, $150 \mathrm{mM} \beta$-mercaptoethanol, and $850 \mu \mathrm{g}$ of bovine serum albumin, pH 8.8, per ml. Each PCR experiment included a control without DNA. Amplifications were performed with an initial denaturation at $95^{\circ} \mathrm{C}$ for $7 \mathrm{~min}$ followed by 35 cycles of denaturation at $94^{\circ} \mathrm{C}$ for $1 \mathrm{~min}$, annealing at $52^{\circ} \mathrm{C}$ for $1 \mathrm{~min}$, and extension at $65^{\circ} \mathrm{C}$ for $8 \mathrm{~min}$. The final extension cycles at $65^{\circ} \mathrm{C}$ for $15 \mathrm{~min}$ were followed by incubation at $4^{\circ} \mathrm{C}$ for $20 \mathrm{~h}$.

After completion of PCR, samples were stored at $4^{\circ} \mathrm{C}$ until gel electrophoresis. A $10-\mu$ l portion of each amplified PCR product was resolved on a gel containing a mixture of $0.75 \%$ agarose and $0.75 \%$ Synergel (Diversified Biotech, Inc., Boston) in $0.5 \times$ Trisborate-EDTA buffer $(89 \mathrm{mM}$ Tris, $89 \mathrm{mM}$ boric acid, and $0.5 \mathrm{M}$ EDTA, pH 8.0), stained with ethidium bromide, and photographed on an UV transilluminator (Polaroid Corp., Cambridge, MA). DNA from the 171 strains of $X$. oryzae pv. oryzae was amplified with the rep-PCR primer ERIC and the IS-PCR primer J3. Experiments were repeated three times to confirm DNA band identities and differences.

Pathotype diversity. In all, 128 strains of $X$. oryzae pv. oryzae were chosen to represent the five putative genetic lineages and were evaluated for virulence diversity on 11 near-isogenic lines, each containing a specific resistance gene. IR24 was used as a susceptible check. Seeds of the near-isogenic lines were obtained from the IRRI, Philippines, and sown in wooden seedboxes. Ten days after sowing, three seedlings of each line were transplanted into 100 -cm-diameter plastic buckets in the greenhouse $\left(28\right.$ to $\left.30^{\circ} \mathrm{C}\right)$. Each bucket was filled with $800 \mathrm{~g}$ of soil and farmyard manure mixed at a ratio of $1: 1(\mathrm{wt} / \mathrm{wt})$. N/P/K was applied approximately at the proportion of $1: 1 / 2: 1 / 3(10-\mathrm{g}$ mixtures of $\mathrm{N} / \mathrm{P} / \mathrm{K}$ per bucket) as the basal dose in the form of ammonium sulfate, single super phosphate, and muriate of potash. Plants were watered daily and were top-dressed with urea $(46 \% \mathrm{~N})$ at the rate of $5 \mathrm{~g}$ per bucket at 30 days after transplanting.

Strains of $X$. oryzae pv. oryzae that were maintained in $15 \%$ glycerol at $-80^{\circ} \mathrm{C}$ were revived on PSA plates and incubated for $72 \mathrm{~h}$ at $28^{\circ} \mathrm{C}$. Each strain was transferred to PSA slants and incubated an additional $48 \mathrm{~h}$ at $28^{\circ} \mathrm{C}$. Inoculum of each strain was prepared by suspending the bacterial cells in $10 \mathrm{ml}$ of sterile distilled water and adjusting (optical density at $600 \mathrm{~nm}=0.3$ ) to approximately $1.2 \times 10^{9} \mathrm{CFU} / \mathrm{ml}$. The experimental unit consisted of the three plants per bucket. Three fully expanded leaves of each plant per bucket (total of nine leaves per experimental unit) were inoculated by the leaf-clip method (24) at 45 days after sowing. Lesion lengths on six inoculated leaves were measured at 21 days after inoculation

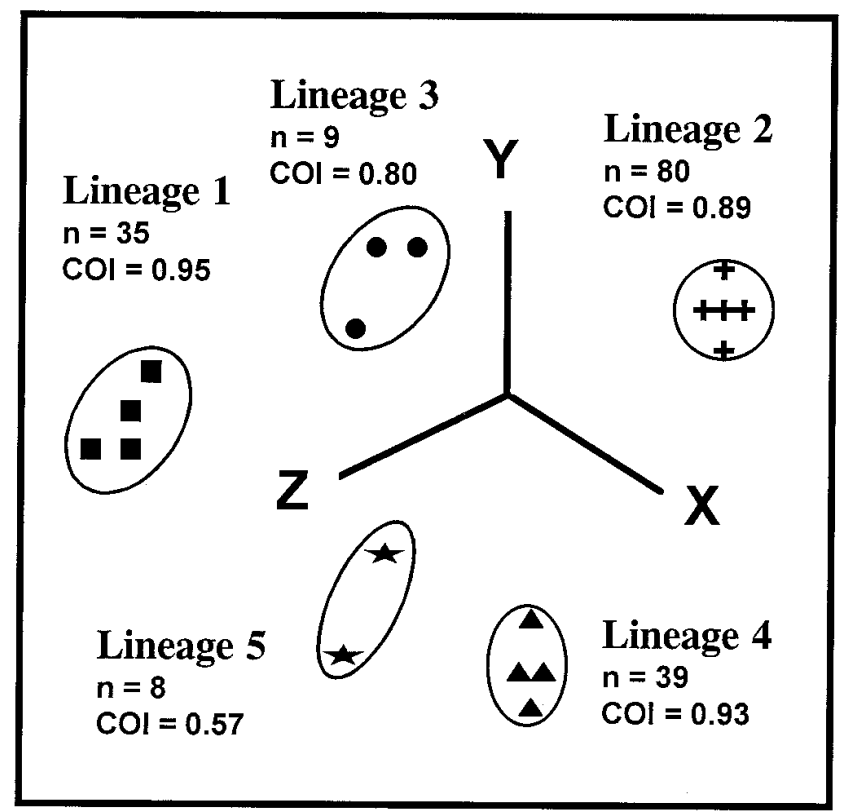

Fig. 2. Multiple correspondence analysis of the 171 strains of Xanthomonas oryzae pv. oryzae analyzed by polymerase chain reaction (PCR) amplification with IS-PCR primer J3 and rep-PCR primer ERIC. Genetic lineages were assigned by the average linkage method (9). The final adjustment of the lineages was made by resampling analysis with 1,000 iterations and the cooccurrence index (COI). Stability of the lineages is indicated by higher COI values (14). The three dimensions (X, Y, and Z) accounted for 68.2, 17.8, and $8.3 \%$, respectively, $($ total $=94.3 \%$ ) of the variation. Identical symbols $(\mathbf{\square}, \mathbf{+}$, $\boldsymbol{\bullet}, \boldsymbol{\Delta}$, and $\star$ ) within circles indicate positions of strains within a cluster as grouped after analysis by both rep-PCR and IS-PCR primers. The total number of strains within each cluster is indicated by $n$; patterns for some strains are identical and, thus, are represented by a single point.

TABLE 2. Frequency of Xanthomonas oryzae pv. oryzae haplotypes by zone

\begin{tabular}{|c|c|c|c|c|c|c|c|c|c|c|c|c|c|}
\hline \multirow[b]{2}{*}{ Zone } & \multicolumn{13}{|c|}{ Frequency of haplotype ${ }^{a}$} \\
\hline & $2(17)^{\mathrm{b}}$ & $5(11)$ & $8(47)$ & $11(11)$ & $12(4)$ & $16(4)$ & $18(3)$ & $19(6)$ & $20(10)$ & $21(7)$ & $22(12)$ & $26(4)$ & $30(5)$ \\
\hline Mechi & 0.03 & 0.11 & 0.19 & 0.16 & 0.00 & 0.03 & 0.00 & 0.03 & 0.05 & 0.03 & 0.03 & 0.00 & 0.05 \\
\hline Koshi & 0.00 & 0.00 & 0.43 & 0.29 & 0.00 & 0.29 & 0.00 & 0.00 & 0.00 & 0.00 & 0.00 & 0.00 & 0.00 \\
\hline Janakpur & 0.00 & 0.00 & 0.60 & 0.10 & 0.10 & 0.00 & 0.05 & 0.05 & 0.00 & 0.00 & 0.10 & 0.00 & 0.00 \\
\hline Narayani & 0.19 & 0.02 & 0.21 & 0.00 & 0.00 & 0.00 & 0.00 & 0.07 & 0.05 & 0.05 & 0.02 & 0.05 & 0.05 \\
\hline Gandaki & 0.17 & 0.00 & 0.48 & 0.03 & 0.03 & 0.03 & 0.03 & 0.00 & 0.12 & 0.00 & 0.03 & 0.00 & 0.00 \\
\hline Lumbini & 0.00 & 0.10 & 0.15 & 0.00 & 0.05 & 0.00 & 0.05 & 0.00 & 0.10 & 0.05 & 0.25 & 0.05 & 0.05 \\
\hline Rapti & 0.20 & 0.60 & 0.00 & 0.00 & 0.00 & 0.00 & 0.00 & 0.00 & 0.00 & 0.20 & 0.00 & 0.00 & 0.00 \\
\hline Bheri & 0.20 & 0.10 & 0.00 & 0.00 & 0.00 & 0.00 & 0.00 & 0.20 & 0.00 & 0.20 & 0.20 & 0.10 & 0.00 \\
\hline
\end{tabular}

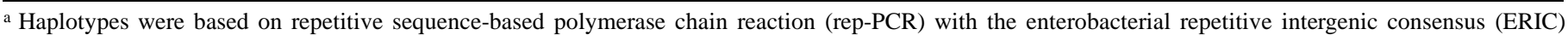

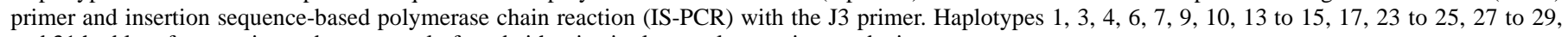
and 31 had low frequencies and were mostly found either in single or only two rice-producing zones.

$\mathrm{b}$ Values in parentheses indicate the number of strains belonging to each haplotype. 
as described by Adhikari et al. (6). Disease reactions were categorized according to lesion length, in which 0 to $3 \mathrm{~cm}$ was classified as resistant $(\mathrm{R})$ or avirulent and more than $3 \mathrm{~cm}$, as susceptible (S) or virulent. The experiment was organized as a split-plot design with near-isogenic lines as the main plot and strains as the subplot. The entire experiment was replicated three times.

Data analysis. The DNA banding patterns of each strain, based on PCR amplification patterns, were compared visually. Briefly, each unique banding pattern generated by a primer set or as a composite of the PCR assays was considered a haplotype. Binary data, i.e., the presence and absence of bands, were coded as 1 or 0 , respectively. A pair-wise comparison of strains was generated by the numerical taxonomy system for personal computer (NTSYSpc, version 1.8; Exeter Biological Software, Setauket, NY). The resulting data were converted to coefficients of dissimilarity (1Jaccard coefficient) and were used for multiple correspondence analysis (version 6; SAS Institute, Inc., Cary, NC) (9). Determination of the number of clusters was based on the consensus among three clustering statistics (cubic cluster criterion, pseudo F statistic, and pseudo $t^{2}$ ) as described previously (9), and strains were assigned to clusters by the average linkage method (SAS Institute, Inc.). The genetic distances among clusters were obtained to determine the relative distance of the clusters from each other. The statistical reproducibility of each cluster was assessed by bootstrap analysis with 1,000 iterations to obtain a co-occurrence index (COI) $(14,51)$. A COI is defined as the proportion of times the specified strains were grouped into the same cluster through 1,000 cycles of bootstrapping and was used as a measure of the strength of the cluster. A graph of the first three dimensions of the multiple correspondence analysis was constructed using the "spin" platform of the JMP software program (SAS Institute, Inc.).
The Shannon information statistic (11) was chosen to estimate genotypic and pathotypic diversity of $X$. oryzae pv. oryzae. This statistic is relatively stable when sample sizes vary (45) and has been used for many fungal plant pathogens $(18,19,26,46)$. Genotypic and pathotypic diversity of $X$. oryzae pv. oryzae within each zone was calculated as $H=-\Sigma p_{i} \ln \left(p_{i}\right)$, in which the $p_{i}$ are the frequencies of the $i$ th haplotype or pathotype in each zone. Variances were calculated as described by Poole (44). The estimated diversity, $H$, was normalized to correct for differences in sample sizes: $H^{\prime}=H / \ln (S)$, in which $S$ is the number of haplotypes or pathotypes in the sample. Total diversity, $H^{\prime}$ TотAL, was partitioned into diversity in improved ( $H_{\text {GIC }}^{\prime}$ for haplotype and $H_{\text {PIC }}^{\prime}$ for pathotype) and traditional ( $H_{\mathrm{GTC}}^{\prime}$ for haplotype and $H_{\mathrm{PTC}}^{\prime}$ for pathotype) cultivars or in diversity from the hills $\left(H_{\mathrm{GH}}^{\prime}\right.$ for haplotype and $H_{\mathrm{PH}}^{\prime}$ for pathotype) and the plains $\left(H_{\mathrm{GP}}^{\prime}\right.$ for haplotype and $H_{\mathrm{PP}}^{\prime}$ for pathotype) of the mean frequencies of all haplotypes or pathotypes in the entire sample. The $t$ statistic was calculated according to the formula $t=\left(H_{\mathrm{A}}^{\prime}-H_{\mathrm{B}}^{\prime}\right) /\left(\text { variance } H_{\mathrm{A}}^{\prime}+\text { variance } H_{\mathrm{B}}^{\prime}\right)^{0.5}$ to determine the significant $(P<0.05)$ differences between $H^{\prime}$ values from the eight rice-producing zones, from the plains and hills and from improved and traditional cultivars.

A data matrix was generated for the virulence data by scoring avirulence as 0 and virulence as 1 . Twenty-six pathotypes of $X$. oryzae pv. oryzae that had unique combinations of virulence and avirulence to the 11 major resistance genes were included in the cluster analysis. From these data, a similarity matrix was derived with the SIMQUAL program (NTSYS-pc, version 1.8; Exeter Biological Software) using Jaccard's coefficient of similarity (47). A phenogram was reproduced by the unweighted pair group method for arithmetic average (UPGMA) in the SAHN procedure. Bootstrap analysis (14) was performed with 1,000 replications to

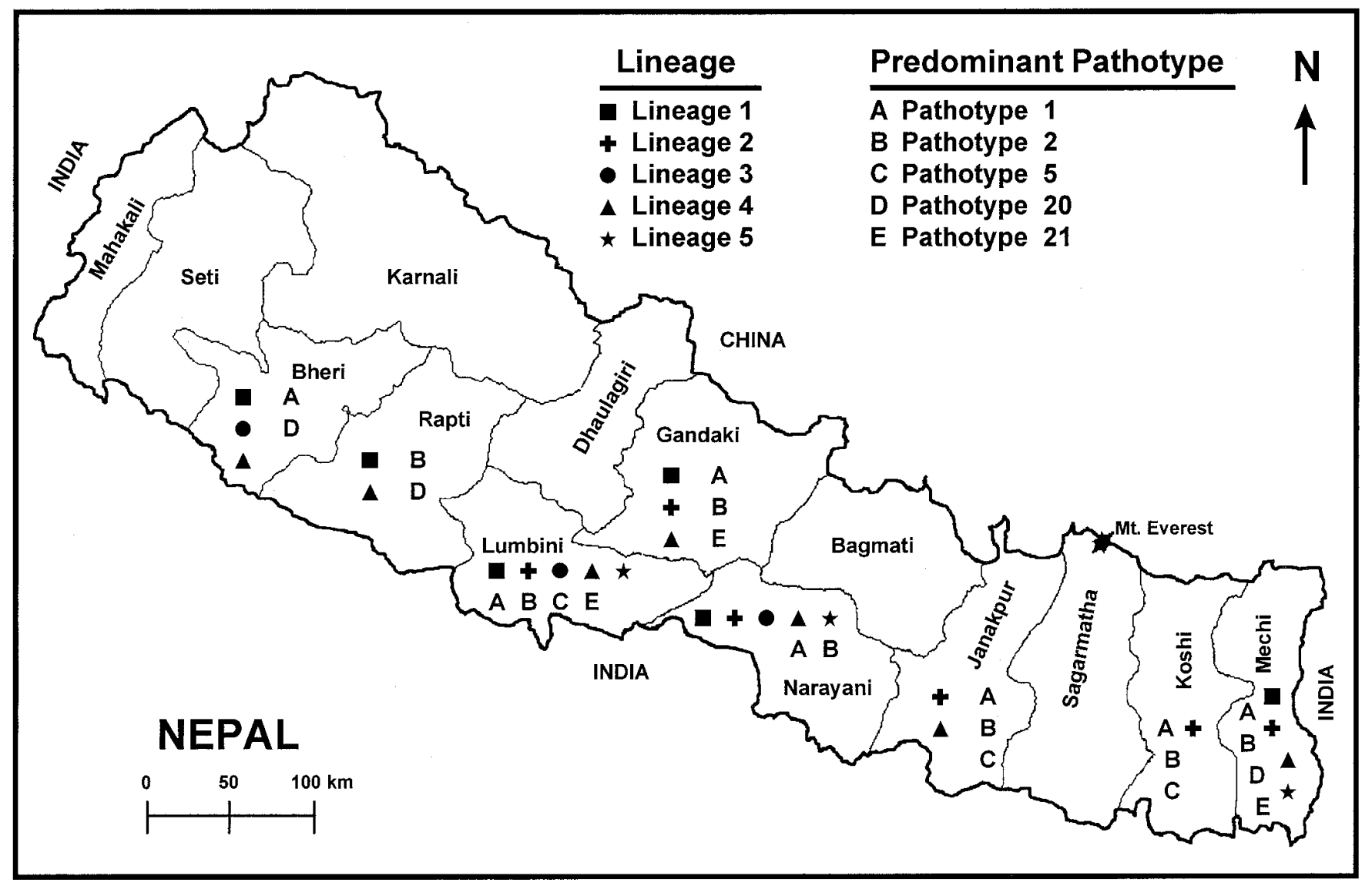

Fig. 3. Distribution of five genetic lineages and five predominant pathotypes of Xanthomonas oryzae pv. oryzae in the eight rice-producing zones of Nepal. A total of 171 strains was analyzed using IS-PCR primer J3 and rep-PCR primer ERIC. Five distinct genetic lineages were revealed by multiple correspondence analysis (9). Twenty-six pathotypes were detected among a subset of 128 strains of $X$. oryzae pv. oryzae by inoculating 11 near-isogenic lines containing a single gene for resistance. Pathotypes 1, 2, 5, 20, and 21 were the most predominant in the populations of X. oryzae pv. oryzae in Nepal. 
determine the reproducibility of the phenogram $(15,16)$. Finally, the 26 pathotypes were grouped into different clusters using Jaccard's coefficient of similarity. Correlation of the virulence and molecular data was determined by comparison of the two similarity matrices using the MXCOMP program of NTSYS-pc.

\section{RESULTS}

Genotypic diversity. Amplification with the IS primer J3 resulted in 13 to 18 DNA fragments per strain, and 27 total band positions were scored. The rep-PCR ERIC primer amplified 9 to 13 DNA fragments per strain, and 25 total band positions were scored. Seventeen and eleven bands were polymorphic with the J3 and ERIC primers, respectively. The DNA fingerprint patterns generated by the $\mathrm{J} 3$ and ERIC primers were referred to as molecular haplotypes. Each primer differentiated 13 haplotypes from the collections of $X$. oryzae pv. oryzae (Fig. 1). Thirty-one molecular haplotypes were found among the 171 strains from eight rice-producing zones in Nepal (Table 2). A single haplotype (haplotype 8) dominated the $X$. oryzae pv. oryzae populations in six zones, but was absent in Rapti and Bheri (Table 2). The five other common haplotypes, haplotypes $2,5,11,20$, and 22 , occurred at multiple sites but at different frequencies. The remaining 25 haplotypes were detected only in a few sites (data not shown).

Genotypic diversity was high in all zones sampled (Table 1), and no significant $(P<0.05)$ differences were revealed by $t$ tests. There were no significant differences between the pathogen subpopulations collected from traditional rice cultivars $\left(H_{\mathrm{GTC}}^{\prime}=0.80\right)$ versus the improved rice cultivars $\left(H_{\mathrm{GIC}}^{\prime}=0.84\right)$ or between the plains $\left(H_{\mathrm{GP}}^{\prime}=0.84\right)$ and the hills $\left(H_{\mathrm{GH}}^{\prime}=0.74\right)$.

Cluster analysis. On the basis of multiple correspondence analysis, the 171 strains of $X$. oryzae pv. oryzae constituted five putative genetic lineages (Fig. 2). The common lineages were lineage 2 ( $n=80,11$ haplotypes), lineage 4 ( $n=39$, five haplotypes), and lineage 1 ( $n=35$, seven haplotypes). Lineages 3 ( $n=9$, five haplotypes) and 5 ( $n=8$, three haplotypes) contained few strains and haplotypes. The overall mean genetic distance was 0.64 . The aver- age genetic distance within lineages ranged from 0.14 (lineage 1) to 0.50 (lineage 5 ) and between lineages ranged from 0.46 to 0.86 . Bootstrap analysis of the consensus phenogram indicated that there were significant $(P<0.05)$ differences between lineages. The COI values for the five genetic lineages ranged from 0.57 to 0.95 . Most rice-producing zones in Nepal contained more than one lineage, but no lineage was found in all zones (Fig. 3).

Pathotype diversity. The strains of $X$. oryzae pv. oryzae were polymorphic for virulence on the 10 near-isogenic lines with resistance genes Xa1, Xa2, Xa3, Xa4, xa5, Xa7, xa8, Xa11, Xa14, and $X a 21$. The strains were all virulent on the IRBB10 line with $X a 10$. About $42 \%$ of the strains were virulent to IRBB21 with the Xa21 gene. Among the 128 strains of $X$. oryzae pv. oryzae tested, 26 pathotypes were identified (Table 3 ). Pathotype 1 comprised $32 \%$ of the strains; these strains were virulent to all major resistance genes tested. Pathotype 2 attacked all major resistance genes except Xa21. The majority of strains in pathotypes $4,5,6,7,15$, 16 , and 22 were virulent on two to three major resistance genes including $X a 21$. Cluster analysis of virulence data with UPGMA revealed five clusters, with a coefficient of similarity of 0.48 (Fig. 4). Cluster 1 contained $56 \%$ of the total strains including pathotypes $1,2,4,15$, and 22 . These were all virulent to $\mathrm{Xa4}$, $x a 5, \mathrm{Xa}$, and $\mathrm{Xa21}$ (except for strains of pathotype 2). Strains of pathotypes 7 and 9 formed cluster 5 and were avirulent to $\mathrm{Xa} 4, \mathrm{xa} 5, \mathrm{Xa}$, and $X a 21$. Cluster 3 was the most heterogeneous group and contained strains of 10 pathotypes. Clusters 2 and 4 contained four and five pathotypes, respectively. In general, the 26 pathotypes fell into two categories: those found over a wide geographic area (i.e., different rice-producing zones) and those restricted to a single zone. Five predominant pathotypes, pathotypes $1,2,5,20$, and 21 , were widely distributed in most rice-producing zones (Fig. 3). The remaining pathotypes were detected in one or two zones. For example, pathotype 11 was found only in Gandaki, and pathotypes 25 and 26 were found only in Janakpur (data not shown). There were no significant $(P<0.05)$ differences in pathotype diversity among zones. The populations of $X$. oryzae pv. oryzae from the plains $\left(H_{\mathrm{PP}}^{\prime}=0.77\right)$ and the hills $\left(H_{\mathrm{PH}}^{\prime}=0.75\right)$ and local $\left(H_{\mathrm{PTC}}^{\prime}=0.76\right)$

TABLE 3. Pathotypic diversity of the 128 strains of Xanthomonas oryzae pv. oryzae on 11 near-isogenic lines containing a single gene for resistance

\begin{tabular}{|c|c|c|c|c|c|c|c|c|c|c|c|c|}
\hline \multirow[b]{2}{*}{ Pathotype } & \multirow[b]{2}{*}{$\begin{array}{l}\text { No. of } \\
\text { strains }\end{array}$} & \multicolumn{11}{|c|}{ Near-isogenic lines and known resistance genes ${ }^{a}$} \\
\hline & & $\begin{array}{c}\text { IRBB1 } \\
(X a 1)\end{array}$ & $\begin{array}{c}\text { IRBB2 } \\
(X a 2)\end{array}$ & $\begin{array}{c}\text { IRBB3 } \\
(X a 3)\end{array}$ & $\begin{array}{c}\text { IRBB4 } \\
(X a 4)\end{array}$ & $\begin{array}{c}\text { IRBB5 } \\
(x a 5)\end{array}$ & $\begin{array}{c}\text { IRBB7 } \\
(X a 7)\end{array}$ & $\begin{array}{c}\text { IRBB8 } \\
(x a 8)\end{array}$ & $\begin{array}{c}\text { IRBB } 10 \\
(X a 10)\end{array}$ & $\begin{array}{c}\text { IRBB11 } \\
(X a 11)\end{array}$ & $\begin{array}{c}\text { IRBB } 14 \\
(X a 14)\end{array}$ & $\begin{array}{c}\text { IRBB21 } \\
(X a 21)\end{array}$ \\
\hline 1 & 41 & $\mathrm{~S}^{\mathrm{b}}$ & $\mathrm{S}$ & $\mathrm{S}$ & $\mathrm{S}$ & $\mathrm{S}$ & $\mathrm{S}$ & $\mathrm{S}$ & $\mathrm{S}$ & $\mathrm{S}$ & $\mathrm{S}$ & $\mathrm{S}$ \\
\hline 2 & 31 & $\mathrm{~S}$ & $\mathrm{~S}$ & $\mathrm{~S}$ & $\mathrm{~S}$ & $\mathrm{~S}$ & $\mathrm{~S}$ & $\mathrm{~S}$ & $\mathrm{~S}$ & $\mathrm{~S}$ & $\mathrm{~S}$ & $\mathrm{R}$ \\
\hline 3 & 3 & $\mathrm{~S}$ & $\mathrm{~S}$ & $\mathrm{~S}$ & $\mathrm{R}$ & $\mathrm{S}$ & $\mathrm{R}$ & $\mathrm{S}$ & $\mathrm{S}$ & $\mathrm{S}$ & $\mathrm{S}$ & $\mathrm{R}$ \\
\hline 4 & 1 & $\mathrm{~S}$ & $\mathrm{~S}$ & $\mathrm{~S}$ & $\mathrm{R}$ & $\mathrm{S}$ & $\mathrm{R}$ & $\mathrm{S}$ & $\mathrm{S}$ & $\mathrm{R}$ & $\mathrm{S}$ & $\mathrm{S}$ \\
\hline 5 & 3 & $\mathrm{~S}$ & $\mathrm{~S}$ & $\mathrm{~S}$ & $\mathrm{R}$ & $\mathrm{R}$ & $\mathrm{S}$ & $\mathrm{R}$ & $\mathrm{S}$ & $\mathrm{S}$ & $\mathrm{S}$ & $\mathrm{S}$ \\
\hline 6 & 1 & $\mathrm{~S}$ & $\mathrm{~S}$ & $\mathrm{~S}$ & $\mathrm{R}$ & $\mathrm{R}$ & $\mathrm{R}$ & $\mathrm{S}$ & $\mathrm{S}$ & $\mathrm{S}$ & $\mathrm{R}$ & $\mathrm{S}$ \\
\hline 7 & 1 & $\mathrm{R}$ & $\mathrm{R}$ & $\mathrm{S}$ & $\mathrm{R}$ & $\mathrm{R}$ & $\mathrm{R}$ & $\mathrm{S}$ & $\mathrm{S}$ & $\mathrm{S}$ & $\mathrm{S}$ & $\mathrm{S}$ \\
\hline 8 & 4 & $\mathrm{~S}$ & $\mathrm{~S}$ & $\mathrm{~S}$ & $\mathrm{R}$ & $\mathrm{R}$ & $\mathrm{S}$ & $\mathrm{S}$ & $\mathrm{S}$ & $\mathrm{S}$ & $\mathrm{R}$ & $\mathrm{R}$ \\
\hline 9 & 1 & $\mathrm{~S}$ & $\mathrm{~S}$ & $\mathrm{R}$ & $\mathrm{R}$ & $\mathrm{R}$ & $\mathrm{R}$ & $\mathrm{R}$ & $\mathrm{S}$ & $\mathrm{S}$ & $\mathrm{S}$ & $\mathrm{R}$ \\
\hline 10 & 3 & $\mathrm{~S}$ & $\mathrm{~S}$ & $\mathrm{~S}$ & $\mathrm{~S}$ & $\mathrm{R}$ & $\mathrm{R}$ & $\mathrm{S}$ & $\mathrm{S}$ & $\mathrm{S}$ & $\mathrm{S}$ & $\mathrm{R}$ \\
\hline 11 & 3 & $\mathrm{~S}$ & $\mathrm{~S}$ & $\mathrm{~S}$ & $\mathrm{~S}$ & $\mathrm{R}$ & $\mathrm{R}$ & $\mathrm{R}$ & $\mathrm{S}$ & $\mathrm{S}$ & $\mathrm{S}$ & $\mathrm{R}$ \\
\hline 12 & 1 & $\mathrm{~S}$ & $\mathrm{R}$ & $\mathrm{S}$ & $\mathrm{S}$ & $\mathrm{R}$ & $\mathrm{R}$ & $\mathrm{S}$ & $\mathrm{S}$ & $\mathrm{S}$ & $\mathrm{S}$ & $\mathrm{R}$ \\
\hline 13 & 2 & $\mathrm{~S}$ & $\mathrm{~S}$ & $\mathrm{~S}$ & $\mathrm{~S}$ & $\mathrm{~S}$ & $\mathrm{R}$ & $\mathrm{S}$ & $\mathrm{S}$ & $\mathrm{S}$ & $\mathrm{R}$ & $\mathrm{R}$ \\
\hline 14 & 1 & $\mathrm{~S}$ & $\mathrm{~S}$ & $\mathrm{~S}$ & $\mathrm{R}$ & $\mathrm{S}$ & $\mathrm{R}$ & $\mathrm{S}$ & $\mathrm{S}$ & $\mathrm{S}$ & $\mathrm{R}$ & $\mathrm{R}$ \\
\hline 15 & 1 & $\mathrm{~S}$ & $\mathrm{~S}$ & $\mathrm{~S}$ & $\mathrm{~S}$ & $\mathrm{~S}$ & $\mathrm{R}$ & $\mathrm{S}$ & $\mathrm{S}$ & $\mathrm{R}$ & $\mathrm{S}$ & $\mathrm{S}$ \\
\hline 16 & 5 & $\mathrm{~S}$ & $\mathrm{~S}$ & $\mathrm{~S}$ & $\mathrm{R}$ & $\mathrm{R}$ & $\mathrm{S}$ & $\mathrm{S}$ & $\mathrm{S}$ & $\mathrm{S}$ & $\mathrm{S}$ & $\mathrm{S}$ \\
\hline 17 & 3 & $\mathrm{R}$ & $\mathrm{S}$ & $\mathrm{S}$ & $\mathrm{R}$ & $\mathrm{S}$ & $\mathrm{S}$ & $\mathrm{R}$ & $\mathrm{S}$ & $\mathrm{R}$ & $\mathrm{R}$ & $\mathrm{R}$ \\
\hline 18 & 2 & $\mathrm{R}$ & $\mathrm{S}$ & $\mathrm{S}$ & $\mathrm{S}$ & $\mathrm{S}$ & $\mathrm{S}$ & $\mathrm{R}$ & $\mathrm{S}$ & $\mathrm{S}$ & $\mathrm{R}$ & $\mathrm{R}$ \\
\hline 19 & 1 & $\mathrm{~S}$ & $\mathrm{~S}$ & $\mathrm{~S}$ & $\mathrm{~S}$ & $\mathrm{~S}$ & $\mathrm{~S}$ & $\mathrm{R}$ & $\mathrm{S}$ & $\mathrm{R}$ & $\mathrm{S}$ & $\mathrm{R}$ \\
\hline 20 & 4 & $\mathrm{~S}$ & $\mathrm{~S}$ & $\mathrm{~S}$ & $\mathrm{~S}$ & $\mathrm{R}$ & $\mathrm{S}$ & $\mathrm{S}$ & $\mathrm{S}$ & $\mathrm{S}$ & $\mathrm{S}$ & $\mathrm{R}$ \\
\hline 21 & 3 & $\mathrm{R}$ & $\mathrm{S}$ & $\mathrm{S}$ & $\mathrm{S}$ & $\mathrm{S}$ & $\mathrm{S}$ & $\mathrm{R}$ & $\mathrm{S}$ & $\mathrm{R}$ & $\mathrm{S}$ & $\mathrm{R}$ \\
\hline 22 & 1 & $\mathrm{R}$ & $\mathrm{S}$ & $\mathrm{S}$ & $\mathrm{R}$ & $\mathrm{S}$ & $\mathrm{S}$ & $\mathrm{S}$ & $\mathrm{S}$ & $\mathrm{S}$ & $\mathrm{S}$ & $\mathrm{S}$ \\
\hline 23 & 2 & $\mathrm{~S}$ & $\mathrm{~S}$ & $\mathrm{R}$ & $\mathrm{R}$ & $\mathrm{R}$ & $\mathrm{S}$ & $\mathrm{S}$ & $\mathrm{S}$ & $\mathrm{S}$ & $\mathrm{S}$ & $\mathrm{R}$ \\
\hline 24 & 3 & $\mathrm{~S}$ & $\mathrm{~S}$ & $\mathrm{R}$ & $\mathrm{S}$ & $\mathrm{S}$ & $\mathrm{S}$ & $\mathrm{S}$ & $\mathrm{S}$ & $\mathrm{S}$ & $\mathrm{R}$ & $\mathrm{R}$ \\
\hline 25 & 5 & $\mathrm{~S}$ & $\mathrm{~S}$ & $\mathrm{~S}$ & $\mathrm{R}$ & $\mathrm{R}$ & $\mathrm{S}$ & $\mathrm{S}$ & $\mathrm{S}$ & $\mathrm{S}$ & $\mathrm{S}$ & $\mathrm{R}$ \\
\hline 26 & 2 & $\mathrm{~S}$ & $\mathrm{~S}$ & $\mathrm{~S}$ & $\mathrm{~S}$ & $\mathrm{~S}$ & $\mathrm{~S}$ & $\mathrm{R}$ & $\mathrm{S}$ & $\mathrm{S}$ & $\mathrm{S}$ & $\mathrm{R}$ \\
\hline
\end{tabular}

a Near-isogenic lines containing a single gene for resistance were used to characterize pathotypes among 128 strains of $X$. oryzae pv. oryzae.

b $\mathrm{S}=$ susceptible and $\mathrm{R}=$ resistant. 
and improved $\left(H_{\text {PIC }}^{\prime}=0.77\right)$ rice cultivars were not significantly different.

At least three patterns were observed between the molecular haplotypes and pathotypes: (i) groups of strains with identical pathotypes (e.g., pathotype 1 or 2 ) from different populations exhibited multiple haplotypes (Fig. 4); (ii) groups of strains from different populations that had the same haplotype (e.g., haplotype 8) usually had multiple pathotypes (Fig. 4); and (iii) groups of strains from the same population (e.g., Janakpur) with the same haplotypes (e.g., haplotype 8) often had identical pathotypes (e.g., pathotype 25). When the similarity matrix of virulence data was compared with that generated by the PCR data, the correlation coefficient was 0.52 (data not shown), which indicated a weak relationship between the two types.

\section{DISCUSSION}

High genotypic diversity of $X$. oryzae pv. oryzae exists throughout Nepal. Diversities of $X$. oryzae pv. oryzae populations collected from traditional and improved rice cultivars were similar, suggesting that host diversity does not affect pathogen diversity. Based on a comparison of different agroecosystems and cultivars in the Philippines, Ardales et al. (10) also suggested that host diversity did not strongly affect pathogen diversity.

George et al. (17) used PCR and RFLP markers to compare strains of $X$. oryzae pv. oryzae from Indonesia and the Philippines. They found that the predominant strains in the pathogen collec-

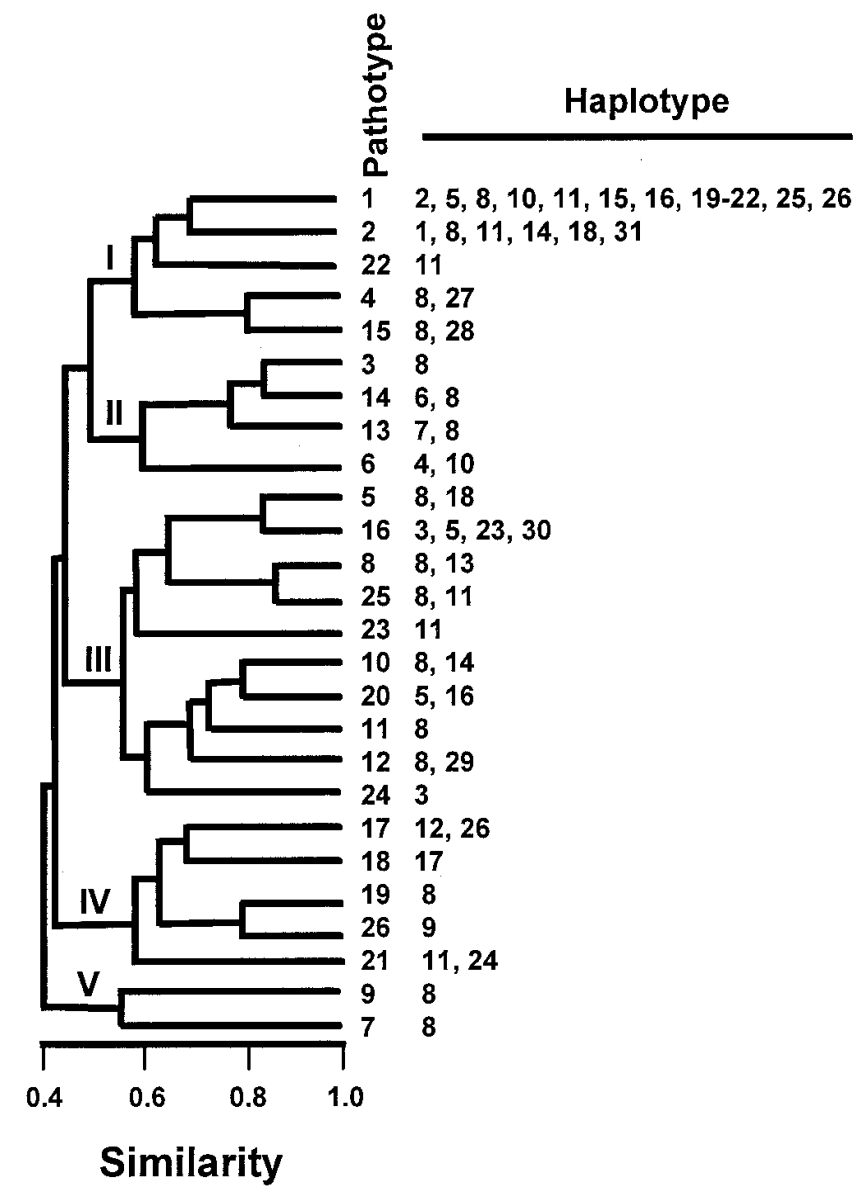

Fig. 4. Phenogram of Xanthomonas oryzae pv. oryzae strains based on virulence to 11 near-isogenic lines containing a single gene for resistance. A data matrix was generated for the virulence data by scoring avirulence as 0 and virulence as 1 . From these data, a similarity matrix was derived with the SIMQUAL program (NTSYS-pc, version 1.80; Exeter Biological Software, Setauket, NY) using Jaccard's coefficient of similarity (47). A phenogram was reproduced by the unweighted pair group method for arithmetic average in the SAHN program. tions from both countries were closely related and concluded that there was regional movement of the pathogen due to germ plasm exchange. Although the population within a zone was generally heterogeneous, in some cases, we detected genetically similar haplotypes in different zones of Nepal, suggesting that there might be migration of $X$. oryzae pv. oryzae. Most of the strains (70\%) tested in this study were collected from a single rice variety, Mansuli, that is grown in different locations in Nepal. The prevalence of the same haplotypes in different rice-producing zones could be due to the widespread cultivation of Mansuli in different zones, and this cultivar may have served as a source of dissemination of the pathogen within the country.

One of the goals of this study was to investigate the pathogenic relatedness of populations of $X$. oryzae pv. oryzae from diverse geographic areas. Because most of the Nepalese strains of $X$. oryzae pv. oryzae used in our previous studies were virulent to the five resistance genes commonly used in the IRRI rice differential cultivars, little diversity in terms of pathotypes was detected $(6,9)$. In this study, the expanded set of 11 near-isogenic lines allowed for greater differentiation of pathogen diversity. On the basis of virulence analysis of the 128 strains collected from eight rice-producing zones, it appears that $X$. oryzae pv. oryzae populations in Nepal are very different from those reported in most rice-producing countries in Asia (9,36). A high level of pathogenic variability within putative genetic lineages 1,2 , and 4 also was observed.

In this study, most strains defeated all of the rice resistance genes tested. The increased virulence to these resistance genes occurred among strains within lineage 2 (Fig. 2) and within cluster 1 (Table 3 , Fig. 4). Thus, currently available sources of major resistance genes are unlikely to provide effective control against the populations of $X$. oryzae pv. oryzae that currently exist in Nepal. The $X a 21$ gene was found to condition resistance to many strains of $X$. oryzae. pv. oryzae from other countries $(48,54)$. Although the $\mathrm{Xa} 21$ gene offers resistance to some Nepalese strains of $X$. oryzae pv. oryzae, $42 \%$ of the strains tested in this study were virulent to $X a 21$, and these strains of $X$. oryzae pv. oryzae were found in all rice-producing zones of Nepal. Thus, a plan for deployment of this trait should consider the occurrence of populations of $X$. oryzae pv. oryzae that can overcome this resistance gene $(1,32)$.

We observed a partial association between molecular haplotype and pathotype, as shown by the comparison of the similarity matrices. This relationship appears to be due to a high degree of DNA polymorphism among strains within many pathotypes. The partial relationship between the groups determined by the PCR-based assays and virulence indicated that the molecular polymorphism observed in this study was largely independent of virulence. Chen et al. (12) examined the relationship between molecular variation and virulence of the wheat stripe rust fungus (Puccinia striiformis) and found a high degree of molecular polymorphism among isolates that had the same virulence phenotypes. They concluded that the molecular polymorphism observed in P. striiformis was largely independent of host selection for virulence polymorphism.

Strains of $X$. oryzae pv. oryzae isolated from Nepal are pathogenically, genetically, and geographically diverse. This diversity may explain some of the difficulties encountered historically in developing rice cultivars with resistance to $X$. oryzae pv. oryzae in Nepal. The problems of understanding the biology of $X$. oryzae pv. oryzae and controlling bacterial blight have long been challenging. The known geographic distribution of the haplotypes provides a baseline for monitoring the future spread of $X$. oryzae pv. oryzae in other rice-producing areas.

\section{ACKNOWLEDGMENTS}

This work was supported by the Rockefeller Foundation's International Program on Rice Biotechnology (RF 94001 \#251). T. B. Adhikari was in receipt of the Rockefeller Foundation's Biotechnology Career Fellowship. We thank R. C. Basnyat, M. R. White, C. M. Vera Cruz, J. Bai, 
and S.-H. Choi for their assistance and suggestions. We thank D. Skinner, J. Groth, and P. Dhakal for statistical analysis and discussion. We also thank R. Nelson and M. Mazzola for reviewing the manuscript.

\section{LITERATURE CITED}

1. Adhikari, T. B., Basnyat, R. C., and Mew, T. W. 1999. Virulence of Xanthomonas oryzae pv. oryzae on rice lines containing single resistance genes and gene combinations. Plant Dis. 83:46-50.

2. Adhikari, T., Leach, J., and Mew, T. W. 1996. Bacterial blight of rice and its control in Nepal. Integr. Pest Manage. Rev. 1:91-95.

3. Adhikari, T. B., and Mew, T. W. 1988. Research on bacterial blight of rice in Nepal. Page 98 in: Proc. Int. Congr. Plant Pathol., 5th.

4. Adhikari, T. B., and Mew, T. W. 1991. Effect of bacterial blight on growth and yield of rice in Nepal. J. Inst. Agric. Anim. Sci. 12:29-40.

5. Adhikari, T. B., and Mew, T. W. 1994. Resistance of rice to Xanthomonas oryzae pv. oryzae in Nepal. Plant Dis. 78:64-67.

6. Adhikari, T. B., Mew, T. W., and Teng, P. S. 1994. Phenotypic diversity of Xanthomonas oryzae pv. oryzae in Nepal. Plant Dis. 78:68-72.

7. Adhikari, T. B., and Shrestha, S. M. 1989. Distribution and severity of bacterial blight of rice in Nepal. J. Inst. Agric. Anim. Sci. 10:31-38.

8. Adhikari, T., Vera Cruz, C. M., Mew, T. W., and Leach, J. E. 1999. Identification of Xanthomonas oryzae pv. oryzae by insertion sequence-based polymerase chain reaction (IS-PCR). Int. Rice Res. Notes 24:23-24.

9. Adhikari, T. B., Vera Cruz, C. M., Zhang, Q., Nelson, R. J., Skinner, D. Z., Mew, T. W., and Leach, J. E. 1995. Genetic diversity of Xanthomonas oryzae pv. oryzae in Asia. Appl. Environ. Microbiol. 61:966-971.

10. Ardales, E. Y., Leung, H., Vera Cruz, C. M., Mew, T. W., Leach, J. E., and Nelson, R. J. 1996. Hierarchical analysis of spatial variation of the rice bacterial blight pathogen across diverse agroecosystems in the Philippines. Phytopathology 86:241-252.

11. Bowman, K. O., Hutcheson, K., Odum, E. P., and Sheton, L. R. 1971. Comments on the distribution of indices of diversity. Stat. Ecol. Ser. 3: 315-359.

12. Chen, X. M., Line, R. F., and Leung, H. 1993. Relationship between virulence variation and DNA polymorphism in Puccinia striiformis. Phytopathology 83:1489-1497.

13. de Bruijn, F. J. 1992. Use of repetitive (repetitive extragenic element and enterobacterial repetitive intergenic consensus) sequences and the polymerase chain reaction to fingerprint the genomes of Rhizobium meliloti isolates and other soil bacteria. Appl. Environ. Microbiol. 58:2180-2187.

14. Efron, B., and Tibshirani, R. 1993. An Introduction to the Bootstrap. Chapman and Hall, London.

15. Felsenstein, J. 1985. Confidence limits on phylogenies: An approach using the bootstrap. Evolution 39:783-791.

16. Felsenstein, J. 1988. Phylogenies from molecular sequences: Interference and reliability. Annu. Rev. Genet. 22:521-565.

17. George, M. L. C., Bustamam, M., Cruz, W. T., Leach, J. E., and Nelson, R. J. 1997. Movement of Xanthomonas oryzae pv. oryzae in Southeast Asia detected using PCR-based DNA fingerprinting. Phytopathology 87: 302-309.

18. Goodwin, S. B., Allard, R. W., Hardy, S. A., and Webster, R. K. 1992. Hierarchical structure of pathogenic variation among Rhynchosporium secalis populations in Idaho and Oregon. Can. J. Bot. 70:810-817.

19. Groth, J. V., and Roelfs, A. P. 1987. The concept and measurement of phenotypic diversity in Puccinia graminis on wheat. Phytopathology 77: 1395-1399.

20. Hopkins, C. M., White, F. F., Choi, S.-H., Guo, A., and Leach, J. E. 1992. Identification of a family of avirulence genes from Xanthomonas oryzae pv. oryzae. Mol. Plant-Microbe Interact. 5:451-459.

21. Hulton, C. S. J., Higgins, C. F., and Sharp, P. M. 1991. ERIC sequences: A novel family of repetitive elements in the genomes of Escherichia coli, Salmonella typhimurium and other enterobacteria. Mol. Microbiol. 5: 825-834.

22. Jones, R. K., Barnes, L. W., Gonzalez, C. F., Leach, J. E., Alvarez, A. M., and Benedict, A. A. 1989. Identification of low-virulence strains of Xanthomonas campestris pv. oryzae from rice in the United States. Phytopathology 79:984-990.

23. Karganilla, A. D., and Natural, M. P. 1973. A comparative study of culture media for Xanthomonas oryzae. Philipp. Agric. 57:141-152.

24. Kauffman, H. E., Reddy, A. P. K., Hsieh, S. P. Y., and Merca, S. D. 1973. An improved technique for evaluating resistance of rice varieties to Xanthomonas oryzae. Plant Dis. Rep. 57:537-541.

25. Khush, G. S., Mackill, D. J., and Sindhu, G. S. 1989. Breeding rice resistance to bacterial blight. Pages 207-217 in: Bacterial Blight of Rice. International Rice Research Institute, Manila, Philippines.

26. Kolmer, J. A. 1991. Phenotypic diversity in two populations of Puccinia recondita f. sp. tritici in Canada during 1931-1987. Phytopathology 81: 311-315.
27. Leach, J. E., Leung, H., Nelson, R. J., and Mew, T. W. 1995. Population biology of Xanthomonas oryzae pv. oryzae and approaches to its control. Curr. Opin. Biotechnol. 6:298-304.

28. Leach, J. E., Rhoads, M. L., Vera Cruz, C. M., White, F. F., Mew, T. W., and Leung, H. 1992. Assessment of genetic diversity and population structure of Xanthomonas oryzae pv. oryzae with a repetitive DNA element. Appl. Environ. Microbiol. 58:2188-2195.

29. Leach, J. E., and White, F. F. 1991. Molecular probes for disease diagnosis and monitoring. Pages 281-307 in: Rice Biotechnology. G. S. Khush and G. H. Toenniessen, eds. CAB International, Oxon, United Kingdom.

30. Leach, J. E., White, F. F., Rhoads, M. L., and Leung, H. 1990. A repetitive DNA sequence differentiates Xanthomonas campestris pv. oryzae from other pathovars of $X$. campestris. Mol. Plant-Microbe Interact. 3:238-246.

31. Leung, H., Nelson, R. J., and Leach, J. E. 1993. Population structure of plant pathogenic fungi and bacteria. Adv. Plant Pathol. 10:157-205.

32. Lin, X. H., Zhang, D. P., Xie, Y. F., Gao, H. P., and Zhang, Q. 1996. Identifying and mapping a new gene for bacterial blight resistance in rice based on RFLP markers. Phytopathology 86:1156-1159.

33. Louws, F. J., Fulbright, D. W., Stephens, C. T., and de Bruijn, F. J. 1994. Specific genomic fingerprints of phytopathogenic Xanthomonas and Pseudomonas pathovars and strains generated with repetitive sequences and PCR. Appl. Environ. Microbiol. 60:2286-2295.

34. Louws, F. J., Fulbright, D. W., Stephens, C. T., and de Bruijn, F. J. 1995. Differentiation of genomic structure by rep-PCR fingerprinting to rapidly classify Xanthomonas campestris pv. vesicatoria. Phytopathology 85:528-536.

35. Lupski, J. R., and Weinstock, G. M. 1992. Short, interspersed repetitive DNA sequences in prokaryotic genomes. J. Bacteriol. 174:4525-4529.

36. Mew, T. W. 1987. Current status and future prospects of research on bacterial blight of rice. Annu. Rev. Phytopathol. 25:359-382.

37. Mew, T. W. 1989. An overview of the world bacterial blight situation. Pages 7-12 in: Bacterial Blight of Rice. International Rice Research Institute, Manila, Philippines.

38. Mew, T. W., Alvarez, A. M., Leach, J. E., and Swings, J. 1993. Focus on bacterial blight of rice. Plant. Dis. 77:5-12.

39. Mew, T. W., Vera Cuz, C. M., and Medalla, E. S. 1992. Changes in race frequency of Xanthomonas oryzae pv. oryzae in response to rice cultivars planted in the Philippines. Plant Dis. 76:1029-1032.

40. Nelson, R. J., Baraoidan, M. R., Vera Cruz, C. M., Yap, I. V., Leach, J. E., Mew, T. W., and Leung, H. 1994. Relationship between phylogeny and pathotype for the bacterial blight pathogen of rice. Appl. Environ. Microbiol. 60:3275-3283.

41. Ogawa, T., Yamamoto, T., Khush, G. S., and Mew, T. W. 1991. Breeding of near-isogenic lines of rice with single genes for resistance to bacterial blight pathogen (Xanthomonas campestris pv. oryzae). Jpn. J. Breed. 41: 523-529.

42. Ou, S. H. 1985. Rice Diseases. Commonwealth Mycological Institute, Kew, Surrey, United Kingdom.

43. Owen, R. J., and Borman, P. 1987. A rapid biochemical method for purifying high molecular weight bacterial chromosomal DNA for restriction enzyme analysis. Nucleic Acids Res. 15:3631.

44. Poole, R. W. 1974. An Introduction to Quantitative Ecology. McGrawHill, New York.

45. Sheldon, A. L. 1969. Equitability indices: Dependence on the species count. Ecology 50:466-467.

46. Sicard, D., Michalakis, Y., Dron, M., and Neema, C. 1997. Genetic diversity and pathogenic variation of Colletotrichum lindemuthianum in the three centers of diversity of its host, Phaseolus vulgaris. Phytopathology 87:807-813.

47. Sneath, P. H. A., and Sokal, R. R. 1973. Numerical Taxonomy: The Principles and Practices of Numerical Classification. W. H. Freeman and Co., San Francisco.

48. Song, W.-Y., Wang, G.-L., Chen, L., Kim, H.-S., Pi, L.-Y., Holsten, T., Wang, B., Zhai, W.-X., Zhu, L.-H., Fauquet, C., and Ronald, P. C. 1995. A receptor kinase-like protein encoded by the rice disease resistance gene Xa21. Science 270:1804-1806.

49. Stern, M. J., Ames, G. F. L., Smith, N. H., Robinson, E. C., and Higgins, C. F. 1984. Repetitive palindromic sequences: A major component of the bacterial genome. Cell 37:1015-1026.

50. Swings, J., Van der Mooter, M., Vauterin, L., Hoste, B., Gillis, M., Mew, T. W., and Kersters, K. 1990. Reclassification of the causal agents of bacterial blight (Xanthomonas campestris pv. oryzae) and bacterial leaf streak (Xanthomonas oryzae (ex Ishiyama, 1992)) sp. nov. rev. Int. J. Syst. Bacteriol. 40:309-311.

51. Vera Cruz, C. M., Ardales, E. Y., Skinner, D. Z., Talag, J., Nelson, R. J., Louws, F. J., Leung, H., Mew, T. W., and Leach, J. E. 1996. Measurement of haplotypic variation in Xanthomonas oryzae pv. oryzae within a single field by rep-PCR and RFLP analyses. Phytopathology 86:1352-1359.

52. Versalovic, J., Koeuth, T., and Lupski, J. R. 1991. Distribution of repeti- 
tive DNA sequences in eubacteria and application to fingerprinting of bacterial genomes. Nucleic Acids Res. 19:6823-6831.

53. Versalvoc, J., Schneider, M., de Bruijn, F. J., and Lupski, J. R. 1994. Genomic fingerprinting of bacteria using repetitive sequence-based polymerase chain reaction. Methods Mol. Cell. Biol. 5:25-40.

54. Wang, G.-L., Song, W.-Y., Ruan, D.-L., Sideris, S., and Ronald, P. C. 1996. The cloned gene, Xa21, confers resistance to multiple Xanthomonas oryzae pv. oryzae isolates in transgenic plants. Mol. Plant-Microbe Interact. 9:850-855.

55. Yoshimura, S., Yoshimura, A., Iwata, N., McCouch, S. R., Rbenes, M.
L., Baraoidan, M. R., Mew, T. W., and Nelson, R. J. 1995. Tagging and combining bacterial blight resistance genes in rice using RAPD and RFLP markers. Mol. Breed. 1:375-387.

56. Yoshimura, S., Yoshimura, A., Nelson, R. J., Mew, T. W., and Iwata, N. 1992. RFLP analysis of introgressed chromosomal segments in three near-isogenic lines of rice for bacterial blight resistance genes, $X a 1, X a 3$, and Xa4. Jpn. J. Genet. 67:29-37.

57. Yun, C. H. 1991. Molecular characterization of a repetitive element of Xanthomonas oryzae pv. oryzae. Ph.D. dissertation. Kansas State University, Manhattan. 